\title{
KONSEP GURU DAN ANAK DIDIK DALAM PENDIDIKAN AKHLAK MENURUT IBNU MASKWAIH
}

\author{
Ayu Lestari \\ IAI AL-Azhaar Lubuklinggau \\ aylestari@gamail.com
}

\begin{abstract}
ABSTRAK
Pendidikan akhlak merupakan hal penting untuk dibahas dan dirumuskan, khususnya pada era globalisasi saat ini. Krisis moral yang terjadi saat ini begitu memprihatinkan, mulai dari kalangan anak-anak, remaja dan dewasa. Oleh karena itu, memahami konsep pendidikan akhlak yang lengkap perlu untuk dikembangkan dan diaplikasikan. Konsep pendidikan akhlak begitu banyak dibicarakan oleh banyak kalangan, tidak terkecuali oleh para pemikir Islam. Konsep pendidikan akhlak menurut Ibn Maskawaih salah satu yang akan di analisis dalam tulisan ini. Konsep pendidikan akhlak dalam tulisan ini difokuskan pada konsep interaksi guru dan anak didik. Interaksi yang dibangun antara anak guru dan siswa adalah interaksi eduktif yang sadar akan tujuan akhir yaitu pembentukan akhlak terpuji bagi siswa. Dalam proses interaksi guru dan anak didik harus berjalan hubungan cinta kasih. Hal ini sebagaimana yang diungkapkan oleh Ibnu Maskawih bahwa guru adalah pendidik setelah orang tua yang memilki peran penting dalam membentuk akhlak siswa.
\end{abstract}

Kata Kunci: Interaksi, Konsep Akhlak Ibn Maskawaih.

\section{ABSTRACT}

Moral education is an important thing to discuss and formulate, especially in the current era of globalization.Die morele krisis wat vandag gebeur, is so kommerwekkend, wat wissel van kinders, adolessente en volwassenes. Therefore the formulation of the concept of moral education needs to be noticed. The concept of moral education so much talked about by many, not least by the thinkers of Islam. The concept of moral education according to Ibn Maskawaih one of which will be analyzed in this paper. The concept of moral education in this paper focuses on the concept of teacher and student interaction. The interaction between teachers and students is an educcessive interaction that is aware of the ultimate goal of forming good morality for students. In the process of moral formation according to Ibn Maskawaih there must be relationship of love between educators and students. This is as expressed by Ibn Maskawaih that teachers are 
I24 | Jurnal Tarbawi Vol. 14. No. 2. Juli - Desember 2017

educators after parents who have an important role in shaping the morals of students.

Keywords: Interaction, Concept morals of Ibn Maskawaih 


\section{PENDAHULUAN}

Salah satu misi utama agama Islam adalah untuk menyempurnakan akhlak manusia. Dengan tujuan itu manusia diharapkan menjadi makhluk yang berakhlak, yakni mahkluk yang bertanggung jawab sepenuhnya atas segala perbuatan yang dilakukan, baik maupun buruk. Akhlak al Karimah yang diajarkan dalam Islam merupakan orientasi yang harus dipegang oleh setiap muslim. (Nurkholis Madjid, 2008: 6)

Saat ini pendidikan akhlak menjadi hal yang perlu untuk dibahas dan dibicarakan, ini berkaitan dengan terjadinya dekadensi moral yang sangat memprihatinkan. Hampir semua kasus yang berkaitan dengan krisis moral terjadi dikalangan pelajar, baik tingat pemula maupun remaja dan dewasa. Banyak contoh kasus terkait dekandasi moral misalnya banyak remaja yang mengakses situs-situs porno kemudian melakukan perbuatan seks bebas. Disamping itu di era Globalisasi, di mana arus informasi yang begitu banyak dan beragam. Informasi yang beragam tersebut tidak hanya berupa pengetahuan, melainkan berbagai nilai-nilai positif dan negatif. Kemudian yang lebih penting lagi pengaruh globalisasi adalah pengaruh nilainilai seperti materialisme, konsumerisme, hedonisme, kekerasan, dan penyalahgunaan narkoba yang dapat merusak moral masyarakat.

Oleh karenanya, dalam menghadapi globalisasi tersebut sebaiknya kita tidak boleh bersikap apriorimenolak apa saja yang datang bersama arus globalisasi. Sebaiknya kita harus bersikap akmodatif serta selektif dalam memilih dan menanamkan akhlak yang baik pada peserta didik agar dapat mempersiapkan mereka dalam menghadapi tantangan globalisasi. Jasmani dan rohani merupakan dua unsur substansional yang terakait dalam pembinaan akhlak. Pendidikan dan pembinaan akhlak hal yang perlu di prioritaskan dan dijaikan otoritas setiap masa dan waktu. Letak pentingnya pembinaan akhlak dapat dilihat dalam firman Allah dalam Al-Qur'an Q.s al-Ahzab ayat 21:

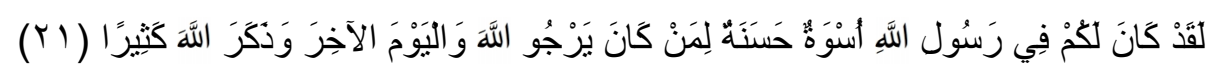

Artinya: Sesungguhnya telah ada pada (diri) Rasulullah itu suri teladan yang baik bagimu (yaitu) bagi orang yang mengharap (rahmat) Allah dan (kedatangan) hari kiamat dan Dia banyak menyebut Allah. (Departemen Agama RI, 2009: 336)

Dalam rangka penanaman akhlak tersebut pendidikan menjadi kunci utama. Pendidikan mempunyai peran penting dalam sosialisasi nilai-nilai kepada peserta didik, maka diperlukan sistem pendidikan yang bermutu dan sesuai dengan perkembangan zaman. (Said Agil Husain al-Munawar, tth: 6) 
Dalam proses penanaman nilai-nilai akhlak interaksi guru dan anak didik menjadi hal yang penting. Dengan terciptanya interaksi yang baik anatara guru dan anak didik maka pesen-pesan akhlak akan lebih mudah tersampaikan. Oleh karena itu, sangat urgen jika dilakukan kajian tentang konsep-konsep etika Islam yang menjadi pilar pengembangan pendidikan akhlak, dengan jalan mengkaji konsep pendidikan akhlak yang digagas oleh ulama Islam. Diantaranya adalah konsep akhlak menurut Ibn Maskawaih yang bisa dijadikan sebagai rujukan untuk menggagas konsep ideal dan praksis tentang pendidikan karakter yang bersumber dari pemikiran para ulama atau filosof muslim.

Berdasarkan latar belakang masalah, tulisan ini fokus dengan konsep interaksi guru dan anak didik menurut konsep pendidikan akhlak Ibn Maskawaih. Sedangkan tujuan penelitian ini adalah untuk memetakan kosntruksi pemikiran pendidikan akhlak dalam Islam menurut Ibn Maskawaih, mengenal sosok Ibn Maskawaih sebagai salah seorang filosof muslim yang banyak pengaruhnya dalam kajian Islam, terutama gagasan-gagasan fenomenalnya tentang konsep etika dalam Islam.

\section{TELAAH PUSTAKA}

Tulisan Terkait pendidikan akhlak secara umum banyak, namun terkait pendidikan akhlak menurut Ibnu Maskwaih ada beberapa Jurnal yang penulis jadikan rujukan dan pertimbangan untuk penulisan yang saya lakukan selanjutnya.

Nur Hamim, Jurnal dengan tema Pendidikan Akhlak, Komparasi pendidikan Ibn Maskawaih dan al-Ghazali. Latar belakang penulisan karya ini yaitu penulis melihat sejarah perkembangan etika Islam bahwa terdapat penyimpangan diantara kedua tokoh ini. Dimana tradisi yang di wariskan oleh Ibnu Maskwaih adalah tradisi rasional dan Al-Ghazali adalah tradisi Mistis atau sufi. Dalam penulisan disimpulkan bahwa nampak jelas kalau Ibnu Miskawaih membangun teori etikanya merujuk kepada pernyataan-pernyataan moral al-Qur"an dan al-Sunnah dengan ketelitian abstraksi dan analisis dengan menggunakan metode-metode dan kategori-kategori filsafat. Oleh karenanya, menurut Madjid Fakhry, konsep etika Ibn Maskawaih adalah etika moralitas skriptual. Sedangkan konsep etika al-Ghazali adalah etika religius, karena teori etikanya berakar dari konsepsi al-Qur"an, al-Sunnah, konsep-konsep teologi, kategori-kategori filsafat, dan sufisme. ( Nur Hamim, 2014: vol 18)

Rosif, Jurnal dengan judul Dialektika pendidikan Etika menurut Ibn Maskawaih.Tulisan ini mendeskripsikan pendidikan etika menurut Ibnu Miskawaih, 
sekaligus menganalisis dinamika pemikiran pendidikan Ibnu Miskawaih tentang pendidikan etika. Penelitian ini menunjukkan bahwa pada dasarnya konsep pendidikan etika dapat dilaksanakan dengan proses ta'dib, secara sederhana adalah sebagai suatu usaha peresapan (instilling) dan penanaman (inculcation) adab pada diri manusia dalam pendidikan. Dengan begitu adab dapat diartikan sebagai content atau kandungan yang harus ditanamkan dalam proses pendidikan Islam. ( Rosif, 2015: Vol. 3 Nomor 2).

Tulisan ini akan menjadi salah satu rujukan untuk tulisan selanjutnya, penulis selanjutnya, menulis tindak hanya konsep pendidikan akhlak tetapi bagaimana hubungan guru dan anak didik dalam proses pendidikan akhlak menurut Ibn Maskawaih.

\section{PEMBAHASAN}

\section{Biografi Ibn Maskawaih}

Nama lengkap Ibn Maskawaih adalah Abu Ali al-khazin Ahmad ibn Muhammad ibn Yaqub bin Maskawaih. Ibn Maskawaih lahir di Ray (sekarang teheran). Beliau dilahirkan pada tahun 320H/932 M dan meninggal dunia di Isfahan tahun 421 H/1030M. Memperhatikan tahun lahirnya hingga wafatnya, tampaknya Ibn Maskawaih dipastikan hidup pada masa pemerintahan dinasti buwaih yang para tokohnya bermazhab syi'ah. (Syafruddin aziz, 2015: 75-76)

Ibn Maskawaih termasuk salah satu pemikir Islam periode klasik yang terkenal dengan teori-teori akhlak Islam. Sebagai bukti atas kebesarannya, ia telah menulis banyak karya yang membahas masalah akhlak, diantaranya: Tahzib al-Akhlaq (tentang moralitas), Thaharah al-Hubs (penyucian jiwa), al-fauz al-akbar (kiat memperoleh kebahagiaan dalam hidup), kitab al-Sa'adah (buku tentang kebahagiaan), dan lain sebagainya. (Abuddin Nata, 2000:6)

Ibnu Miskawaih pada dasarnya adalah seorang ahli sejarah, kimia, dan moralis. Disebutkan bahwa ia tertarik pada al-Kimia bukan demi ilmu pengetahuan, melainkan demi emas dan harta, dan ia sangat patuh kepada guru-gurunya. Namun disebutkan juga bahwa pada tahun-tahun menjelang masa tuanya ia menggeluti ilmu moral. Seperti, membina kesederhanannya dalam melayani nafsu, ketegaran dalam menundukkan diri yang serakah dan kebijakan dalam mengatur dorongan-dorongan yang tak rasional. Dan nampaknya mayoritas dari karya tulisnya ditulis ketika ia mendalami ilmu akhlak tersebut.(MM. Syarif, 1985: 84). 
Sebelumnya Ibnu maskwaih memiliki karakter kurang baik sebagaimana dalam buku Menuju kesempurnaan akhlak terjemahan dari Tahdzib al-Akhlak Ibn Maskawaih mengatakan dirinya sebagai berikut: " Perlu diketahui, bahwa saya, setelah beranjak dewasa dapat menjauhkan diri dari hal-hal yang buruk ini, melalui perjuangan keras dan berat. Mudah-mudahan anda, wahai pencari kemuliaan dan keutamaan moral dapat berhasil seperti saya, agar anda tahu, dan tentu saja menjadi penunjuk jalan keberhasilan anda, sebelum melangkah lebih jauh ke lembah kesesatan, agar menjadi perahu penyelamat, sebelum anda tenggelam dalam samudera kehancuran. Dengan nama Allah saya katakan, jagalah jiwamu wahai saudara-saudara dan anak-anakku! Peluklah erat-erat kebenaran. Milikilah akhlak yang baik. Upayakanlah kearifan yang cemerlang. Titilah jalan yang lurus. Renungkan seluruh keadaan jiwamu, dan ingatingatlah selalu fakultas-fakultasnya ".(Ibn Maskawaih, 1994: 71)

Maka keterangan itu menandakan bahwa apa yang ia tulis dalam kitab ini adalah hasil dari pemikirannya dan pembuktiannya. Dimana ketika seseorang itu benar ingin merubah keadaannya (akhlaknya) maka ia mampu, dengan mengendalikan jiwanya, Mensucikan jiwanya dari perbuatan-perbuatan yang dapat mengotori hatinya.

\section{Pendidikan akhlak Menurut Ibnu Maskwaih}

Khuluq merupakan suatu keadaan jiwa. Keadaan ini yang menyebabkan jiwa bertindak tanpa berfikir atau dipertimbangkan secara mendalam. Keadaan ini ada dua jenis, pertama yaitu alamiah dan bertolak dari watak. Misalnya orang yang mudah marah karena hal yang paling kecil, atau tertawa berlebihan karena hal yang sangat biasa. Kedua, perbuatan yang tercipta melalui kebiasaan dan latihan. Pada mulanya keadaan ini terjadi karena pertimbangan dan dipikirkan, kemudian melalui praktik yang terus menerus menjadi karakter. (Ibn Maskawaih, 1994: 56)

Setiap karakter dapat berubah, Sedangkan apapun yang berubah maka sifatnya tidak alami. Karena tidak ada karakter yang alami. (Ibn Maskawaih, 1994: 58). Ibnu Miskawaih percaya bahwa akhlak itu pada keseluruhannya diperoleh dan dipelajari. la terpengaruh oleh faktor-faktor waktu, tempat, situasi dan kondisi masyarakat, adat, tradisi, sistemnya, dan harapan-harapannya. Dari sini jelas perlunya pendidikan, manfaatnya dan pengaruhnya pada remaja dan anak-anak dan dari syariat agama yang benar yang merupakan petunjuk buat Allah buat para makhluknya. 
Ibnu Miskawaih memandang manusia sebagai makhluk yang memiliki macammacam daya. Menurutnya dalam diri manusia terdapat tiga daya, yaitu daya bernafsu (nafs al-bahimiyah) sebagai daya terendah, daya berani (nafs al-sabu"iyah), dan daya berfikir (nafs al-natiqah) sebagai penyempurnanya. Ketiga bagian daya tersebut harus digunakan oleh manusia secara seimbang, karena apabila hanya mengutamakan salah satu, maka akan menjerumuskan manusia kepada kejahatan dan kebinasaan. (Ibn Maskawaih, 1994: 43-44)

Karakter mucul ketika awal pertumbuhan anak-anak, anak-anak tidak menutupinya dengan sengaja dan sadar seperti orang tua. Oleh karena itu, pendidikan akhlak masa pertumbuhan anak-anak diperlukan. Orang tua sebagai pendidik pertama memilki kewajiban untuk mendidik anak mentaati syari'at agama.

Syariat agama merupakan faktor yang meluruskan karakter, yang membiasakan mereka untuk membiasakan melakukan perbuatan baik, sekaligus yang mempersiapkan diri mereka untuk menerima kearifan, mengupayakan kebajikan dan mencapai kebahagiaan melalui berfikir dan penalaran yang kuat. (Ibn Maskawaih, 1994: 60)

Tujuan pendidikan akhlak yang dirumuskan Ibn Maskawaih adalah terwujudnya sikap batin yang mampu mendorong secara spontan untuk melahirkan semua perbuatan baik sehingga mencapai kesempurnaan dan memperoleh kebahagian sempurna. Untuk mencapai tujuan yang telah dirumuskan, Ibn Maskawaih menyebutkan beberapa hal yang perlu dipelajari, diajarkan atau dipraktikan. Sesuai konsepnya tetang manusia secara umum Ibn Maskawaih menghendaki agar semua sisi kemanusiaan mendapatkan materi didikan yang memberi jalan bagi tercapainya tujuan pendidikan. Untuk mencapai tujuan tersebut materi yang harus diajarkan dikelompokan menjadi 3 yaitu: Pertama, Hal-hal yang wajib bagi kebutuhan tubuh manusia seperti shalat, puasa dan sa'i. Kedua, hal-hal yang wajib bagi jiwa, misalnya tentang akidah yang benar, motivasi untuk senang terhadap ilmu. Ketiga, hal-hal yang wajib bagi hubungannya dengan manusia lainnya, misalnya materi dalam ilmu muamalat, pertanian, perkawinan, saling menasehati, dan lain.-lain. Ketiga pokok materi tersebut secara garis besar dapat diperoleh dari ilmu-ilmu yang berkaitan dengan pemikiran yang disebut al-ulum al-fikriyah, dan ilmu-ilmu yang berkaitan dengan indra disebut al-u'lum al-bissiyat. (Abuddin Nata, 2000: 12-13) 


\section{Interaksi Guru dan Anak Didik menurut Ibn Maskawaih}

Pendidik yang dalam hal ini guru, ustadz atau dosen memegang peranan penting dalam keberlangsungan kegiatan pengajaran dan pendidikan untuk mencapai tujuan yang ditetapkan. Sedangkan anak didik yang selanjutnya disebut murid, siswa, peserta didik atau mahasiswa merupakan sasaran kegiatan pengajaran dan pendidikan merupakan bagian yang perlu mendapatkan perhatian seksama. Perbedaan anak didik dapat menyebabkan terjadinya perbedaan materi, metode, pendekatan dan sebagainya.

Tercapainya tujuan proses belajar mengajar dalam kegiatan pendidikan dan pengajaran, memerlukan usaha terciptanya interaksi yang baik antara guru yang mengajar dan peserta didik yang belajar. (Suryosubroto, 2009:147)

Interaksi merupakan hubungan antar manusia yang sifat dari hubungan tersebut adalah dinamis artinya hubungan itu tidak statis, selalu mengalami dinamika. (Setiadi, Elly M. dan Kolip Usman, 2011: 62)

Dari interaksi akan menghasilkan produk-produk interaksi, yaitu tata pergaulan yang berupa nilai dan norma yang berupa kebaikan dan keburukan dalam ukuran kelompok tersebut. Pandangan tentang apa yang dianggap baik dan apa yang dianggap buruk tersebut mempengaruhi perilaku sehari-hari. (Setiadi, Elly M. dan Kolip Usman, 201: 38)

Kedua aspek pendidikan (Pendidik dan anak guru) bagi Ibnu Maskwaih mendapat perhatian khusus. Menurutnya orang tua tetap merupakan pendidik yang mula-mula bagi anak-anaknya dengan syari'at sebagai acuan utama materi pendidikannya. Karena peran demikian besar dari orang tua dalam kegiatan pendidikan, maka perlu adanya hubungan harmonis antara orang tua dan anak yang didasarkan cinta kasih. Namun demikian, cinta seseorang kepada gurunya menurut Ibn Maskawaih harus melebihi cintanya kepada orang tuanya sendiri. Alasan yang diajukan karena seorang guru dianggap lebih berperan dalam mendidik kejiwaan muridnya dalam rangka mencapai kebahagian.

Guru berfungsi sebagai orang tua atau bapak ruhani, orang yang dimuliakan dan kebaikan yang diberikan adalah kebaikan Ilahi. Selain itu, guru berperan membawa anak didik kepada kearifan, mengisi jiwa anak dengan kebijaksanaan yang tinggi dan menunjukan kepada mereka kehidupan abadi dan dalam kenikmatan yang abadi pula. Pendidik yang dimaksudkan Ibn Maskawaih adalah manusia ideal seperti yang terdapat pada konsepsinya tentang manusia ideal. Dari pandangan itu, dapat 
diambil suatu pemahaman bahwa guru yang tidak mencapai derajat seperti yang dimaksudkan dinilai sama dengan sorang teman atau saudara, karena dari mereka dapat diambil ilmu dan adab. (Setiadi, Elly M. dan Kolip Usman, 2011: 17-18)

Perlunya hubungan yang didasarkan cinta kasih antara guru dan murid tersebut dipandang demikian penting, karena terkait dengan keberhasilan dalam kegiatan belajar mengajar. Kegiatan belajar mengajar yang didasarkan cinta kasih antara guru dan murid memberi dampak yang positif bagi keberhasilan pendidikan anak. (Setiadi, Elly M. dan Kolip Usman, 2011: 20)

Pendidikan akhlak bagi peserta didik hendaknya dilakukan melalui proses belajar, pendidikan dan kebiasaan, nasihat dan petunjuk serta peringatan dan latihan. Adapun langkah-langkah dalam membentuk akhlak menurut Ibn Maskawaih antara lain: berkemauan dan berlatih terus menerus, untuk hidup secara sopan, santun dan berakhlak serta menjadikan semua pengetahuan dan pengalaman orang lain sebagai cermin hidup dirinya.

Seorang guru dalam hal pendidikan anak hendaknya membiasakan dengan hal-hal yang baik dan usahakan agar anak didik sebisa mungkin membiasakan diri, melakukan kewajiban agama. Lalu pujilah anak didik dihadapannya sekiranya tampak darinya perilaku yang baik. Sebaliknya buat agar ia risih terhadap sesuatu yang tercela yang muncul dalam dirinya. Salahkan dia bila makan, minum, dan berpakaian berlebihan. Hendaknya dia mendengar pujian bila dapat menahan diri. Setelah itu dia harus dididik agar dapat memperhatikan orang lain dalam hal makanan dan agar puas dengan hal yang wajar dan sederhana. (Ibn Maskawaih, 1994: 76)

Dalam buku menuju kesempurnaan akhlak, dikatakan bila seorang pendidik mendapati siswa melakukan perbuatan yang yang bertolak belakang dari hal-hal yang baik, maka yang pertama kali harus dilakukan adalah jangan cerca dia. Mencerca kesalahan anak didik secara terang-terangan didepan orang lain akan membawa anak tersebut kepada keburukan. Seorang pendidik hendaknya menasehati dengan lembut, dan mengatakan bahwa perbuatan yang di lakukan itu bukan merupakan keinginannya. Strategi seperti ini dilakukan ketika guru menghadapi siswa yang menutup-nutupi perbuatannya.

\section{KESIMPULAN}

Konsep akhlak yang ditawarkan Ibn Maskawaih yaitu berdasarkan doktrin jalan tengah. Ibn Maskawaih secara umum memberi pengertian jalan tengah tersebut 
antara lain dengan keseimbangan, moderat dan harmoni, utama, mulia atau posisi tengah antara dua ekstrem. Seperti telah dijelaskan sebelumnya, jiwa manusia ada tiga yaitu: jiwa al-bahimiyah, al-ghadabiyah, dan an-natiqah. Menurut Ibn Maskawaih posisi tengah jiwa al-bahimiyah yaitu al-'iffah yaitu menjaga diri dari perubatan dosa seperti berzina. Selanjutnya posisi tengah jiwa al-ghadabiyah adalah as-sa'jaah atau perwira yaitu keberanian yang diperhitungkan dengan baik untung ruginya. Sedangkan posisi tengah jiwa an-natiqah yaitu al-hikmah yaitu kebijaksanaan. Adapun perpaduan dari ketiga posisi tengah tersebut adalah keadilan atau keseimbangan. (Abudin Nata, 2000: 8-9)

Untuk mewujudkan semua itu pendidikan merupakan wadah yang tepat dalam pembinaan akhlak. Dalam proses pembentukan akhlak menurut Ibnu Maskawaih harus diciptaknnya hubungan cinta kasih antara pendidik dan anak didik. Guru selaku pendidik setelah orang tua memilki peranan penting dalam hal pembentukan akhlak siswa. Guru harus membiasakan siswa dengan hal-hal yang terpuji, artinya seorang guru menjadi teladan bagi siswa. Interaksi yang dibangun antara anak guru dan siswa adalah interaksi eduktaif yang sadar akan tujuan akhir yaitu pembentukan akhlak terpuji bagi siswa. Edi Suardi dalam buku Interaksi dan Motivasi Belajar Mengajar merinci ciri-ciri interaksi belajar mengajar sebagai berikut:

1. Interaksi belajar mengajar memiliki tujuan, yakni untuk membantu anak dalam suatu perkembangan tertentu.

2. Ada suatu prosedur (jalannya interaksi) yang direncana, didesain, untuk mencapai tujuan yang telah ditetapkan.

3. Interaksi belajar-Mengajar ditandai dengan satu penggarapan materi yang khusus.

4. Ditandai dengan adanya aktivitas siswa. Aktivitas siswa merupakan syarat mutlak bagi berlangsungnya interaksi belajar-mengajar.

5. Dalam interaksi Belajar-Mengajar guru berperan sebagai pembimbing. Dalam perannanya sebagai pembimbing ini guru harus berusaha menghidupkan dan memberikan motivasi agar terjadi proses interaksi yang edukatif.

6. Di dalam interaksi belajar-mengajar dibutuhkan disiplin. Disiplin dalam interaksi ini adalah suatu pola tingkah laku yang diatur sedemikian rupa menurut ketentuan yang telah ditaati oleh semua pihak dengan secara sadar, baik pihak guru maupaun pihak siswa.

7. Ada batas waktu. (Sardiman, 2012: 15-16) 
Proses interaksi edukatif adalah suatu proses yang mengandung sejumlah norma. Semua norma itulah yang harus guru transfer kepada anak didik. Oleh karena itu, wajarlah bila interaksi edukatif tidak berproses dalam kehampaan, tetapi dalam penuh makna. Interaksi edukatif sebagai jembatan yang menghidupkan persenyawaan antara pengetahuan dan perbuatan, yang mengantarkan kepada tingkah laku sesuai dengan pengetahuan yang diterima anak didik

\section{DAFTAR PUSTAKA}

Maskawaih Ibnu. 1994. Menuju Kesempurnaan Akhlak. Terj, Helmi Hidayat. Bandung: Mizan

MM. Syarif. 1985. Para Filosof Muslim. Bandung: Mizan

Nata Abuddin. 2000. Pemikiran Para Tokoh Pendidikan Islam: Seri Kajian Filsafat Pendidikan Islam. Jakarta: PT Raja Grafindo Persada

Nur Hamim, Pendidikan Akhlak, Komparasi pendidikan Ibn Maskawaih dan alGhazali, Ulumuna Jurnal Studi Kelslaman. Volume 18 Nomor 1. Juni 2014.

Nurkholis Madjid. 2008. Islam Doktrin dan Peradaban. Jakarta: Paramadina

Rosif, Dialektika Pendidikan Etika, Jurnal Pendidikan Agama Islam Volume 3 Nomor 2. November 2015.

Said Agil Husain al-Munawar. Tt. Aktualisasi Nilai-Nilai Qurani. Jakarta Selatan: Ciputat Press.

Sardiman. 2012. Interaksi dan Motivasi Belajar Mengajar. Jakarta: PT Raja Grafindo Persada

Setiadi, Elly M. dan Kolip Usman. 2011. Pengantar Sosiologi: pemahaman fakta dan gejala permasalahan sosial: teori, aplikasi, dan pemecahannya. Jakarta : Kencana Prenada Media

Suryosubroto. 2009. Proses Belajar Mengajar di Sekolah. Jakarta : Rineka Cipta Syafruddin aziz. 2015. Pemikiran Pendidikan Islam, Kajian tokoh klasik dan Kontemporer. Yogyakarta: Kalimedia 
I34 | Jurnal Tarbawi Vol. 14. No. 2. Juli - Desember 2017 